\title{
Leukocyte Depleted Blood Transfusions and Post-Operative Morbidity: The Role of Leukodepletion Modality
}

\section{Mattia Garancini*, Alberto Delitala, Marco Polese, Luca Degrate and Vittorio Giardini}

Department of General Surgery, San Gerardo Hospital, University of Milano-Bicocca, Italy

Allogenic blood transfusions represent one of the risk factors that has proved to enhance the incidence of post-operative morbidity and in particular the incidence of infective complications [1,2]. As a matter of fact, allogenic blood transfusions may create conditions leading to an immune down-regulation, clinical evidence known in the literature as allogenic blood transfusion-associated immunomodulation (TRIM) [3-6]. Its impact on post-operative course is not negligible considering that peri-operative transfusion rate in large cohorts of patients submitted to colorectal surgery ranges from $25,7 \%$ to $54,9 \%[5,7,8]$.

Leukocyte-depleted blood transfusions (LDBT) have been introduced in many countries over the last years to reduce negative side effects of blood transfusions $[7,9,10]$. On the other hand, several studies founded contrasting results regarding the real effects of LDBT on post-operative morbidity.

Anyway, when the clinical impact of LDBT is analysed, great attention should be paid to the modality of leukocyte-depletion that can be performed in a pre-storage or bedside filtration setting. Filtration of (buffy coat depleted) blood can be performed as pre-storage leukocyte depletion using pre-storage filters within 2 hours from the donation obtaining pre-storage LDBT, or performed after storage at time of transfusion (usually within 42 days from donation) using bedside filters and obtaining bedside filtered LDBT. Previous in vitro studies proved that white blood cell reduction by bedside filtration appears inadequate if compared to pre-storage filtration [11,12]. Furthermore, as it is performed few hours after blood donation, pre-storage leukocyte depletion has proved to be effective in removing leukocytes before cytokines production and before releasing of bioactive substances (histamine, 2-eosinophil cationic protein, eosinophil protein $\mathrm{X}$, myeloperoxidase, and plasminogen activator inhibitor-12) contained in intracellular white cells granulesan; on the contrary, bedside leukocyte filtration is performed just before the transfusion and can occur even several days after the donation, therefore after production and release of cytokines and bioactive substances normally contained in WBC and supposed to be related to TRIM [13-15].

Compared to bedside-filtered, pre-storage LDBT are supposed to be associated with lower TRIM [13-15], but the clinical influence of leukodepletion modality (pre-storage vs bedside filtration) on postoperative morbidity in surgical patients was seldom investigated.

In trauma patients some retrospective studies demonstrated that the use of pre-storage leukoreduction is associated with a reduction of infective complications $[16,17]$. Several studies demonstrated that in open heart surgery leukoreduction reduced post-operative multiple organ dysfunction syndrome, infections and consequent short-term mortality $[18,19]$. A randomized controlled trial (RCT) investigating the effect of different types of leukoreduction modality in surgical patients regards open heart surgery showed that infective complication rates did not differ in patients transfused with pre or post-storage LDBT; this represent the only RCT comparing pre and post-storage LDBT in terms of post-operative complications [18]. Colorectal surgery represents one of the field in which the effects of LDBT has been more frequently studied.

In literature there are 6 randomized controlled trials (RCT) evaluating post-operative morbidity after colorectal surgery in patients transfused with LDBT vs patients transfused with buffy coat depleted transfusions. Four of the studies demonstrated significantly reduced morbidity in patients transfused with LDBT $[4,7,20,21]$; two of them showed similar morbidity between groups, but both of them obtained a trend towards a lower rate of complications after LDBT [10,22]. There are no RCT investigating the effect of different types of leukoreduction modality in patients regards submitted to colorectal surgery. Nevertheless, a recent retrospective study found that post-operative morbidity and in particular post-operative infective morbidity was significantly increased in patients transfused with bedside filtered LDBT compared to patient's administered with pre-storage LDBT [23]. As a consequence, the potential role of pre-storage filtration in reducing post-operative morbidity (in particular infective complications) has already to be clarified.

In literature there are several studies investigating the effect of LDBT in different setting of patients; lots of these studies found that LDBT have a negative effect in terms of post-operative complications or on long-term survival (in oncologic patients) [24-26]. On the other hand, these surveys are mostly based on the comparison between patients transfused and patients not transfused; moreover the leukoreduction modality is sometimes not clearly specified. Basing on these results, transfusions should be restricted even when LDBT are available; nevertheless, it should be considered opportune to investigate which type of blood unit should be administered in patients who strictly necessitate to be transfused.

Since the reduction of post-operative complication is considered a main goal for surgeons of every surgical field, further RCTs comparing different leukodepletion modality in different surgical field should be considered of paramount interest.

Pre-storage leukodepletion is surely an expansive modality, but its real benefit should be clarified even in order to reduce costs related to prolonged hospital stay and for increased post-operative interventional procedures in patients with post-operative complications.

\section{References}

1. Amato A, Pescatori $M$ (2006) Perioperative blood transfusions for the recurrence of colorectal cancer. Cochrane Database Syst Rev: CD005033.

2. Duffy G, Neal KR (1996) Differences in post-operative infection rates between patients receiving autologous and allogeneic blood transfusion: a meta-

*Corresponding author: Garancini Mattia, Department of General Surgery, San Gerardo Hospital, University of Milano Bicocca, Italy, Tel: +39 039 2339783; Fax: +39 039 2339783; E-mail: mattia garancini@yahoo.it

Received December 27, 2013; Accepted December 29, 2013; Published January 02, 2014

Citation: Garancini M, Delitala A, Polese M, Degrate L, Giardini V (2014) Leukocyte Depleted Blood Transfusions and Post-Operative Morbidity: The Role of Leukodepletion Modality. Biol Syst Open Access 3: e108. doi:10.4172/2329-6577.1000e108

Copyright: @ 2014 Garancini M, et al. This is an open-access article distributed under the terms of the Creative Commons Attribution License, which permits unrestricted use, distribution, and reproduction in any medium, provided the original author and source are credited. 
Citation: Garancini M, Delitala A, Polese M, Degrate L, Giardini V (2014) Leukocyte Depleted Blood Transfusions and Post-Operative Morbidity: The Role of Leukodepletion Modality. Biol Syst Open Access 3: e108. doi:10.4172/2329-6577.1000e108

Page 2 of 2

analysis of published randomized and nonrandomized studies. Transfus Med 6: 325-328.

3. Heiss MM, Mempel W, Jauch KW, Delanoff C, Mayer G, et al. (1993) Beneficial effect of autologous blood transfusion on infectious complications after colorectal cancer surgery. Lancet 342: 1328-1333.

4. Jensen LS, Andersen AJ, Christiansen PM (1992) Postoperative infection and natural killer cell function following blood transfusion in patients undergoing elective colorectal surgery. Br J Surg 79: 513-516

5. Busch OR, Hop WC, Hoynck van Papendrecht MA, Marquet RL, Jeekel J (1993) Blood transfusions and prognosis in colorectal cancer. N Engl J Med 328: $1372-1376$

6. Vamvakas EC, Blajchman MA (2001) Deleterious clinical effects of transfusionassociated immunomodulation: fact or fiction? Blood 97: 1180-1195.

7. Jensen LS, Kissmeyer-Nielsen P, Wolff B, Qvist N (1996) Randomised comparison of leucocyte-depleted versus buffy-coat-poor blood transfusion and complications after colorectal surgery. Lancet 348: 841-845.

8. Ferjani AM, Griffin D, Stallard N, Wong LS (2007) A newly devised scoring system for prediction of mortality in patients with colorectal cancer: a prospective study. Lancet Oncol 8: 317-322.

9. Williamson LM, Murphy MF, Llewelyn C, Todd A, Taylor R, et al. (2002) Leucocyte-depleted blood in prevention of post-operative infections following elective orthopaedic and cardiac procedures. Vox Sang 83 Suppl 1: 457-460.

10. Titlestad IL, Ebbesen LS, Ainsworth AP, Lillevang ST, Qvist N, et al. (2001) Leukocyte-depletion of blood components does not significantly reduce the risk of infectious complications. Results of a double-blinded, randomized study, Int $\mathrm{J}$ Colorectal Dis 16: 147-153.

11. Ledent $E$, Berlin $G$ (1994) Inadequate white cell reduction by bedside filtration of red cell concentrates. Transfusion 34: 765-768.

12. Sprogøe-Jakobsen U, Saetre AM, Georgsen J (1995) Preparation of white cellreduced red cells by filtration: comparison of a bedside filter and two blood bank filter systems. Transfusion 35: 421-426.

13. Nielsen HJ, Edvardsen L, Vangsgaard K, Dybkjaer E, Skov PS (1996) Timedependent histamine release from stored human blood products. Br J Surg 83: 259-262.

14. Nielsen HJ, Reimert CM, Pedersen AN, Brünner N, Edvardsen L, et al. (1996) Time-dependent, spontaneous release of white cell- and platelet-derived bioactive substances from stored human blood. Transfusion 36: 960-965.

15. Vamvakas EC, Blajchman MA (2000) Prestorage versus poststorage white cell reduction for the prevention of the deleterious immunomodulatory effects of allogeneic blood transfusion. Transfus Med Rev 14: 23-33.

16. Phelan HA, Gonzalez RP, Patel HD, Caudill JB, Traylor RK, et al. (2010) Prestorage leukoreduction ameliorates the effects of aging on banked blood. $\mathrm{J}$ Trauma 69: 330-337.

17. Friese RS, Sperry JL, Phelan HA, Gentilello LM (2008) The use of leukoreduced red blood cell products is associated with fewer infectious complications in trauma patients. Am J Surg 196: 56-61.

18. van de Watering LM, Hermans J, Houbiers JG, van den Broek PJ, Bouter $\mathrm{H}$, et al. (1998) Beneficial effect of leukocyte depletion of transfused blood on postoperative complications in patients undergoing cardiac surgery: A randomized clinical trial. Circulation 97: 562-568.

19. Vamvakas EC (2007) White-blood-cell-containing allogeneic blood transfusion and postoperative infection or mortality: an updated meta-analysis. Vox Sang 92: 224-232.

20. Skånberg J, Lundholm K, Haglind E (2007) Effects of blood transfusion with leucocyte depletion on length of hospital stay, respiratory assistance and survival after curative surgery for colorectal cancer. Acta Oncol 46: 1123-1130.

21. Tartter PI, Mohandas K, Azar P, Endres J, Kaplan J, et al. (1998) Randomized trial comparing packed red cell blood transfusion with and without leukocyte depletion for gastrointestinal surgery. Am J Surg 176: 462-466.

22. Houbiers JG, Brand A, van de Watering LM, Hermans J, Verwey PJ, et al (1994) Randomised controlled trial comparing transfusion of leucocytedepleted or buffy-coat-depleted blood in surgery for colorectal cancer. Lancet 344: 573-578.

23. Degrate L, Garancini M, Misani M, Poli S, Nobili C, et al. (2011) Right colon left colon, and rectal surgeries are not similar for surgical site infection development. Analysis of 277 elective and urgent colorectal resections. Int $J$ Colorectal Dis 26: 61-69.

24. Ng T, Ryder BA, Chern H, Sellke FW, Machan JT, et al. (2012) Leukocytedepleted blood transfusion is associated with decreased survival in resected early-stage lung cancer. J Thorac Cardiovasc Surg 143: 815-819.

25. Kneyber MC, Grotenhuis F, Berger RF, Ebels TW, Burgerhof JG, et al. (2013) Transfusion of leukocyte-depleted RBCs is independently associated with increased morbidity after pediatric cardiac surgery. Pediatr Crit Care Med 14: 298-305.

26. Perisanidis C, Dettke M, Papadogeorgakis N, Schoppmann A, Mittlböck M, et al. (2012) Transfusion of allogenic leukocyte-depleted packed red blood cells is associated with postoperative morbidity in patients undergoing oral and oropharyngeal cancer surgery. Oral Oncol 48: 372-378. 